\title{
Survival strategies of two small marine ciliates and their role in regulating bacterial community structure under experimental conditions
}

\author{
C. M. Turley, R. C. Newell \& D. B. Robins \\ Institute for Marine Environmental Research, Prospect Place, The Hoe, Plymouth PL1 3DH, United Kingdom
}

\begin{abstract}
Uronema sp. of ca $12 \times 5 \mu \mathrm{m}$ and Euplotes sp. ca $20 \times 10 \mu \mathrm{m}$ were isolated from surface waters of the English Channel. The rapidly motile Uronema sp. has a relative growth rate of $3.32 \mathrm{~d}^{-1}$ and responds rapidly to the presence of bacterial food with a doubling time of only $5.01 \mathrm{~h}$. Its mortality rate is $0.327 \mathrm{~d}^{-1}$ and mortality time is therefore short at $50.9 \mathrm{~h}$ once the bacterial food resource has become limiting. Uronema sp. therefore appears to be adapted to exploit transitory patches when bacterial prey abundance exceeds a concentration of ca $6 \times 10^{6}$ cells $\mathrm{ml}^{-1}$. In contrast, Euplotes sp. had a slower relative growth rate of $1.31 \mathrm{~d}^{-1}$ and a doubling time of ca. $12.7 \mathrm{~h}$, implying a slower response to peaks in bacterial food supply. The mortality rate of $0.023 \mathrm{~d}^{-1}$ is considerably lower than in Uronema and mortality time is as much as $723 \mathrm{~h}$. This suggests that, relative to Uronema, the slower moving Euplotes has a more persistent strategy which under the conditions of our experiment favours a stable equilibrium with its food supply. Grazing activities of these 2 ciliates have an important influence on abundance and size-class structure of their bacterial prey. In the presence of both Uronema and Euplotes, there is some evidence of an initial removal of large rods and squat rods, followed by removal of the smaller cocci before the initial population of bacteria is consumed. This is followed by the appearance of a secondary bacterial assemblage which is associated only with the development of the grazing ciliates and is dominated by small thin rods. Gross growth efficiency of Uronema and Euplotes is ca 27 and $19 \%$ respectively. Hence as much as 73 to $81 \%$ of the carbon ingested with the bacterial food is dissipated through respiration and excretion. Should this occur in natural euphotic waters this process may supplement the DOM release by primary producers. Extracellular DOM production by the ciliates may therefore be of major significance in the maintenance of the secondary population of bacteria, and emphasizes the close interdependence of ciliate predators and bacterial prey in microheterotrophic food webs.
\end{abstract}

\section{INTRODUCTION}

The impact of protozoan grazing on bacterial standing stocks and nutrient regeneration in marine systems has been widely recognised (Pomeroy 1974, Azam et al. 1983, Sieburth 1984). Early studies by Johannes (1965) and Barsdate et al. (1974) implicated protozoans in nutrient regeneration (see also Taylor 1982, Gast \& Horstmann 1983, Sherr et al. 1983, Goldman et al. 1985, Goldman \& Caron 1985). Subsequent studies on nutrient regeneration and material flow through bacteria and bacteriovores have deepened our understanding of marine food webs (Williams 1981, Fenchel 1982a, Sieburth \& Davis 1982, Newell \& Linley 1984, Porter et al. 1985, Caron et al. 1985).

Although the importance of protozoan predation in controlling bacterial numbers has been widely reported (e.g. Haas \& Webb 1979, Sieburth 1979, Sorokin 1981, Fenchel 1982a, b, Sieburth \& Davis 1982, Newell et al. 1983, Andersen \& Fenchel 1985, Gast 1985), there have been few studies on the influence of predation on bacterial community structure or on the more complex interrelations between protozoan predators and their bacterial prey in pelagic systems. Berk et al. (1976), for example, observed significant differences in feeding rate and population density of Uronema with type and population density of the bacterial prey, whilst Sieburth \& Davis (1982) suggested that protozooplankton could both nurture and graze their planktonic food (see also Taylor \& Berger 1976, Taylor et al. 1985).

We have studied interactions between Uronema sp. 
and Euplotes sp. isolated from surface water in the English Channel and their bacterial prey isolated from the same waters. Since we were interested primarily in interactions between ciliates and their bacterial prey we have excluded the influence of DOM release from primary production by conducting all the experiments in the dark. Our results suggest a close interdependency between growth of predator and prey, the size structure and density of the prey being controlled by predation.

\section{MATERLALS AND METHODS}

Isolation and culture. For $\mathrm{cil}$ i a te s, seawater was collected from surface sea waters (Lat $50^{\circ}, 12.0^{\prime} \mathrm{N}$; Long $04^{\circ} 18.0^{\prime} \mathrm{W}$ ) on $11 \mathrm{July} 1984$ and $15 \mathrm{ml}$ subsamples were transferred within 24 h to sterile Petri dishes held at laboratory temperature. Ca 10 infused (boiled for $3 \mathrm{~min}$ in autoclaved $0.45 \mu \mathrm{m}$ pore-size filtered seawater) barley grains were added to each dish and the development of the protozoan population monitored for up to $30 \mathrm{~d}$. After ca $10 \mathrm{~d}$, dense populations of Uronema sp. and Euplotes sp. were found in some cultures. The isolated protozoans were then transferred with ca 100 barley grains into 51 flasks containing 21 autoclaved $0.45 \mu \mathrm{m}$ pore-size filtered seawater, gently aerated and held at $15^{\circ} \mathrm{C}$ in the dark. These formed the low concentration steady-state stock uni-protozoan cultures used for subsequent grazing experiments. B a cteria were isolated from the same seawater samples as the protozoans, using marine agar plates (Oxoid). Isolates of colony-forming bacteria from the plates were subcultured in marine nutrient broth (Oxoid) at $15^{\circ} \mathrm{C}$ and used as a food resource for the grazing experiment.

Experimental procedure. Cultures of the ciliates which had been growing in barley grain infusions were subcultured and were preconditioned with the bacteria as a food source for $4 \mathrm{~d}$ prior to grazing experiments. This resulted in a major increase in protozoan numbers which had by then entered an exponential growth phase. The ciliates from these cultures were harvested by passing through $80 \mu \mathrm{m}$ mesh to remove detritus, gently centrifuging at $700 \mathrm{rpm}$. They were allowed to swim out of the detrital pellet and then resuspended in autoclaved filtered seawater. This centrifugation and washing was repeated 3 times after which the ciliates appeared to be active and healthy.

In order to prepare bacterial prey for the feeding experiments, a culture of the isolated marine bacterium in its exponential growth phase was harvested by centrifugation. The pellet of bacteria was resuspended in autoclaved filtered seawater and recentrifuged. This was repeated 3 times. Mean cell volume of bacterial food varied between 0.07 and $0.17 \mathrm{\mu m}^{3}$ throughout the experiment and was in a range of cell volumes similar to those recorded for natural bacterial assemblages (Fuhrman \& Azam 1982, Fry \& Davies 1985, Sieracki et al. 1985, Turley \& Lochte 1986).

Grazing experiments were carried out in a final volume of $20 \mathrm{ml}$ batch cultures in autoclaved filtered seawater contained in $40 \mathrm{ml}$ volume particle-free sterile vessels. Three replicate vessels were prepared for each of the 31 sampling intervals for both Uronema and Euplotes grazing experiments; the same number of additional control vessels contained bacterial prey only. Bacterial suspension was added to each tube to give a starting concentration of about $2.7 \times 10^{7}$ cells $\mathrm{ml}^{-1}$. Euplotes was added to one set of vessels and Uronema to another to give initial concentrations of 124 cells $\mathrm{ml}^{-1}$ and 93 cells $\mathrm{ml}^{-1}$, respectively.

After inoculation, contents of experimental vessels were gently mixed on an orbital shaker in the dark at $15^{\circ} \mathrm{C}$. Samples were taken at intervals over $30 \mathrm{~d}$. At each time interval, 3 vessels were removed from each of the Uronema, Euplotes and control treatments. At the next time interval, a further 3 vessels were removed from each of the treatments so that errors incurred in repeated subsampling from one vessel were not accumulated. Bacterial and ciliate cell numbers, volumes and growth parameters were then determined on each of the replicates.

Estimation of bacterial numbers, biovolume and frequency of dividing cells. Bacterial numbers were estimated by a 4'6-diamidino-2-phenylindole (DAPI) epifluorescence direct counting technique (Porter \& Feig 1980) using a Leitz Ortholux II microscope giving a final magnification of $\times 1562$. An appropriate volume of sample was filtered to give ca 30 cells field $^{-1}$. The frequency of dividing and divided cells (FDDC, see Davis \& Sieburth 1984) was estimated from 20 fields. Bacterial cells in 10 fields were also classified into the 8 size classes and morphs shown in Table 1 using an eyepiece micrometer. Total bacterial numbers were then calculated from the combined numbers in the 30 fields counted. The carbon equivalent of the bacterial biovolume was calculated assuming a specific gravity of $1.1 \mathrm{~g} \mathrm{~cm}^{-3}$ (Porter 1946, Doetsch \& Cook 1973 , Lamanna et al. 1973), a dry: wet weight ratio of 0.2 (Porter 1946, Luria 1960), and a carbon:dry weight ratio of 0.5 (Luria 1960, Doetsch \& Cook 1973).

Enumeration, biovolume and growth parameters of ciliates. The number of ciliates was determined both by direct counts using a $1 \mathrm{ml}$ SedgewickRafter counter chamber viewed under $\times 50$ magnification and a Coulter Counter model TAII with a population accessory, interfaced with an Apple Ile microcomputer using a Pascal package developed at IMER. Triplicate counts were made with the Coulter Counter 
Table 1. Bacterial cell size and volume used to categorize the bacterial population into 8 different cell sizes and morphological groups

\begin{tabular}{|lccccc|}
\hline Morph or size class & \multicolumn{1}{c|}{$\begin{array}{c}\text { Liameter or width }(\mu \mathrm{m}) \\
\text { range }\end{array}$} & $(\overline{\mathrm{x}})$ & $\begin{array}{c}\text { Mean cell } \\
\text { range }\end{array}$ \\
\hline Minicocci & $0.2-0.4$ & $(0.3)$ & - & - & $(\overline{\mathrm{x}})$ \\
Cocci & $0.4-0.8$ & $(0.6)$ & $0.4-0.8$ & $(0.6)$ & 0.014 \\
Squat rods & $0.4-0.6$ & $(0.5)$ & $0.8-1.2$ & $(1.0)$ & 0.113 \\
Large rods & $0.4-0.6$ & $(0.5)$ & $1.2-2.0$ & $(1.6)$ & 0.196 \\
Very large rods & $0.4-0.6$ & $(0.5)$ & $0.4-1.2$ & $(0.8)$ & 0.314 \\
Small thin rods & 0.4 & & $1.2-2.0$ & $(1.6)$ & 0.101 \\
Large thin rods & 0.4 & & $1.2-1.6$ & $(1.4)$ & 0.201 \\
Vibrios & 0.6 & & & \\
\hline
\end{tabular}

for each sample using an aperture of $200 \mu \mathrm{m}$ giving multi-channel analysis from an equivalent spherical diameter (ESD) of 4 to $80 \mu \mathrm{m}$. The data were then transferred to a GEC main-frame computer for final data processing. Data for each species expressed as volume per channel (i.e. $\mu \mathrm{m}^{3} \times 10^{6} \mathrm{ml}^{-1}$ ) showed clearly the size of the ciliates. The number per $\mathrm{ml}$ in the relevant channels was, however, consistently $\sim 30 \%$ greater than the direct counts using a counting chamber and microscope. This was due to aggregations of detrital material, observed during the direct counts and possibly associated with ciliate grazing (see Stoecker 1984), being counted by the Coulter Counter. Total number of particles in channels where the ciliates were recorded was therefore adjusted to equal the direct counts observed, and the volume recalculated on the revised totals.

An alysis of the CHN of a culture of Euplotes yielded a value of 0.132 pico-g $\mathrm{C}_{\mu \mathrm{m}^{3}}$ compared with a value of 0.088 which has been obtained for other Protozod by Heinbokel (1978). An intermediate value of 0.11 pico-g C $\mathrm{mm}^{3}$, which was also used by Strathmann (1967) for phytoplankton, has been used in our estimates of the carbon equivalent of ciliate biovolume for both Uronema and Euplotes.

Estimation of growth parameters. The mean relative growth rate $\left(\mu_{\mathrm{n}}{ }^{\prime}, \mathrm{d}^{-1}\right)$ of the ciliates has been distinguished from the maximum specific growth rate $\left(\mu_{n}\right)$ to describe the growth of ciliates under the particular conditions of our experiments. The results should not be confused with genotypic differences between the maximum specific growth rates achieved under steady-state conditions, but are of value in describing the relative rate of growth under experimental conditions (see also Turley \& Lochte 1985). Mean relative growth rates $\left(\mu_{n}{ }^{\prime}\right)$ were calculated for each time interval and mean relative growth rates over the exponential phase were used to compare growth of Uronema and Euplotes by

$$
\mu_{\mathrm{n}}^{\prime}\left(\mathrm{d}^{-1}\right)=\left(\ln \mathrm{N}_{\mathrm{t}_{2}}-\ln \mathrm{N}_{\mathrm{t}_{1}}\right) /\left(\mathrm{t}_{2}-\mathrm{t}_{1}\right)
$$

Doubling time $\left(\mathrm{D}_{\mathrm{n}}{ }^{\prime}, \mathrm{h}\right)$ was calculated from

$$
D_{\mathrm{n}}{ }^{\prime}(\mathrm{h})=\frac{0.693 \times 24}{\mu_{\mathrm{n}}^{\prime}}
$$

Similarly, the rate of decrease of the ciliate population, which is analogous to the mortality rate $\left(M_{n}{ }^{\prime}, d^{-1}\right)$ can be used to compare grazer populations under particular experimental conditions. Relative mortality rate $\left(\mathrm{M}_{\mathrm{n}}{ }^{\prime}, \mathrm{d}^{-1}\right)$ was calculated during exponential death phase by Formula (1), mortality time $\left(\mu \mathrm{M}^{\prime}, \mathrm{h}\right)$ being the equivalent death estimation to the doubling time (Equation 2) under the particular conditions of the experiment. A crude estimate of gross growth efficiency ([carbon incorporation into ciliate biomass/ bacterial carbon consumed] $\times 100$ ) was calculated from the carbon equivalent of protozoan production determined from the maximum point on the growth curve and the carbon equivalent of bacterial consumption, taking into account both bacterial numbers and growth rate (determined from FDDC) over the same period.

All results were plotted as multidimensional and contour diagrams using the programs GRAZBLK and GRAZCON respectively (NERC Computing Service, Plymouth).

\section{RESULTS AND DISCUSSION}

The significance of small ciliates as grazers of bacteria in pelagic systems has received increasing recognition in recent years (Sieburth 1984, Porter et al. 1985). Uronema sp. used in our experiments was ca $12 \times 5 \mu \mathrm{m}$ (Fig. 1) whilst Euplotes sp. was ca $20 \times 12$ $\mu \mathrm{m}$ (Fig. 2). Uronema sp. was similar in size to that described by Johnson et al. (1982) but both Uronema and Euplotes are small for their genera (see also Curds et al. 1974). In both cases the size and structure of the oral ciliature is appropriate to the capture of bacteria (see also Fenchel \& Small 1980), many of which can be seen associated with the cilia (Fig. 1 \& 2). 


\section{Growth strategies in the presence of bacterial prey}

Numbers of ciliates and their bacterial prey are plotted as a function of time in Fig. $3 \& 4$. In both cases the increase in numbers of ciliates is associated with a decline in bacterial numbers which subsequently reach a relatively uniform cell density. In Uronema cultures, ciliate population density declined rapidly over a period of ca $100 \mathrm{~h}$, leaving a residual bacterial population of ca $6 \times 10^{6}$ cells $\mathrm{ml}^{-1}$ (Fig. 3). As seen in Fig. 4, however, Euplotes cell numbers persisted at ca $2 \times 10^{3}$ cells $\mathrm{ml}^{-1}$ throughout most of the experimental period, despite the decline in bacteria to 2 to $3 \times 10^{6}$ cells $\mathrm{ml}^{-1}$. Since the bacteria were actively growing
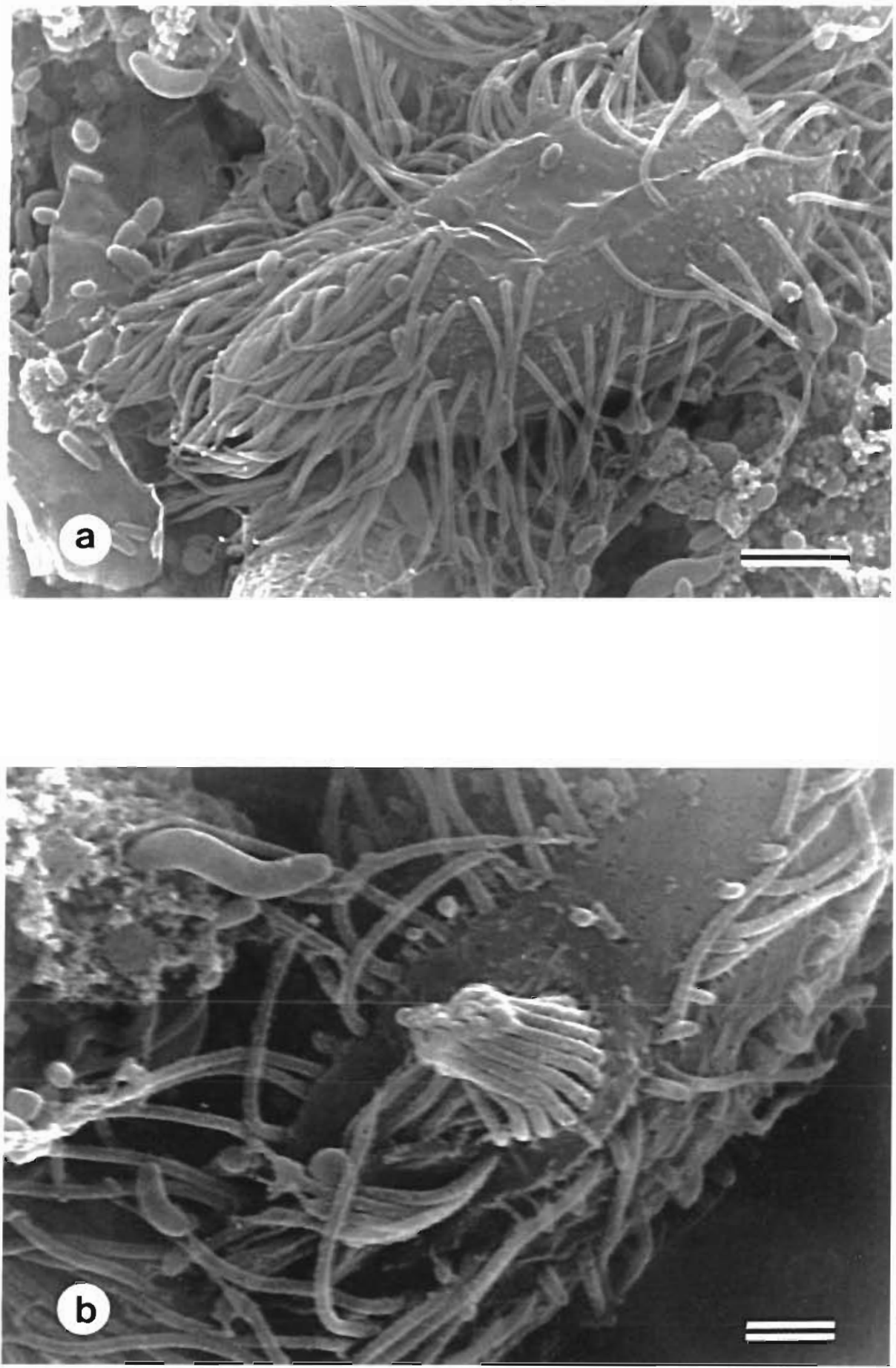

Fig. 1 Uronema sp. Scanning electron micrographs. (a) The small ovoid hymenostome ciliate with its numerous cilia. Bar $=2 \mu \mathrm{m}$. (b) Its relatively small mouth and associated oral ciliature. $\mathrm{Bar}=1 \mu \mathrm{m}$. Bacteria of different sizes and shapes can be seen amongst the cilia 
throughout the whole of the experimental period (Fig. 8), the Euplotes population may have been partially sustained by cropping bacterial production after the initial consumption of biomass, although the bac- terial food resource is clearly insufficient to support the maximum ciliate density recorded at $87 \mathrm{~h}$.

Clear differences also emerge between Uronema and Euplotes when the cell volume is plotted as a

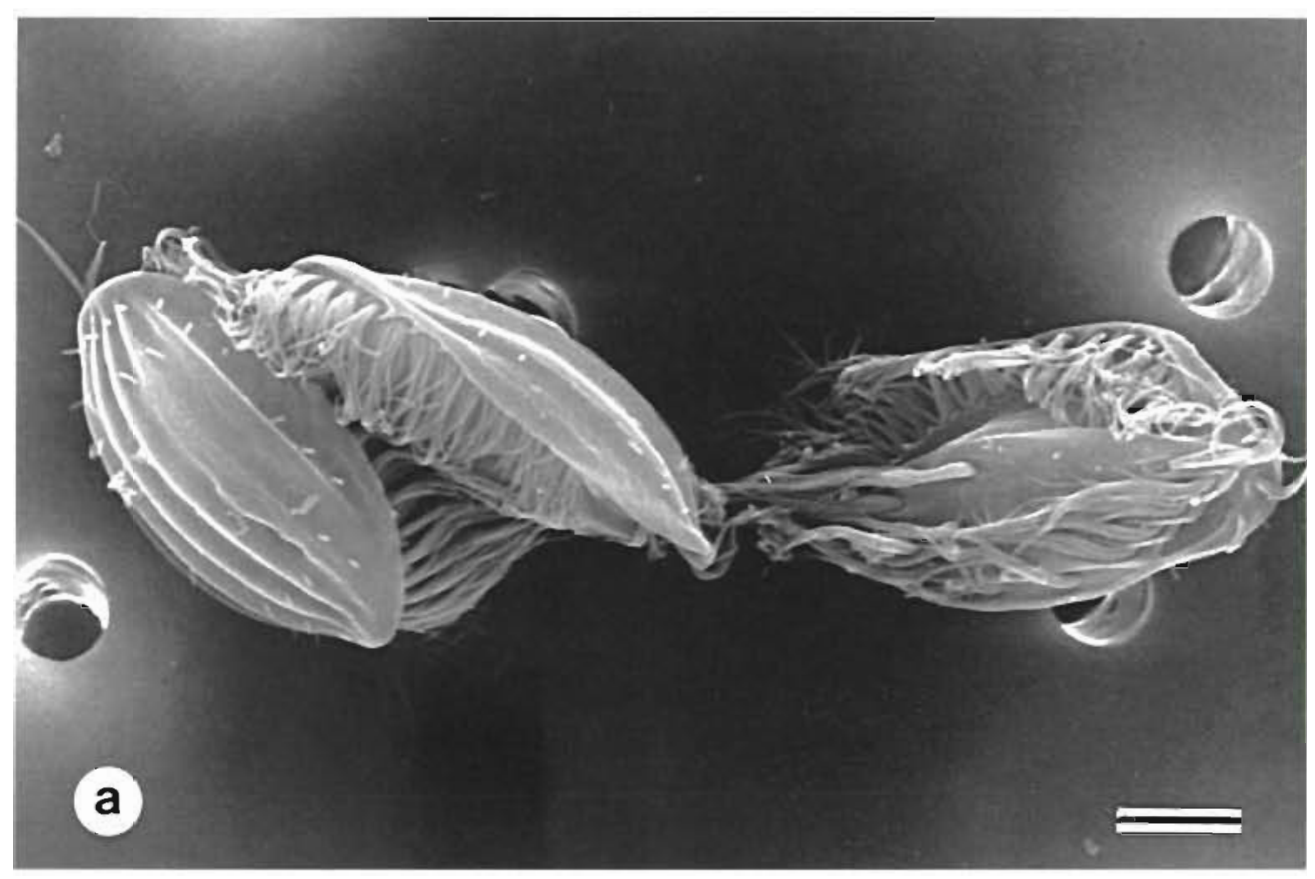

Fig. 2. Euplotes sp. Scanning electron micrographs. (a) The small dorso-ventrally flattened hypotrich with its fused ventral cilia forming cirri used for motility. (b) Its large dorsal oval cavity and complex ciliature. Bars $=5 \mu \mathrm{m}$

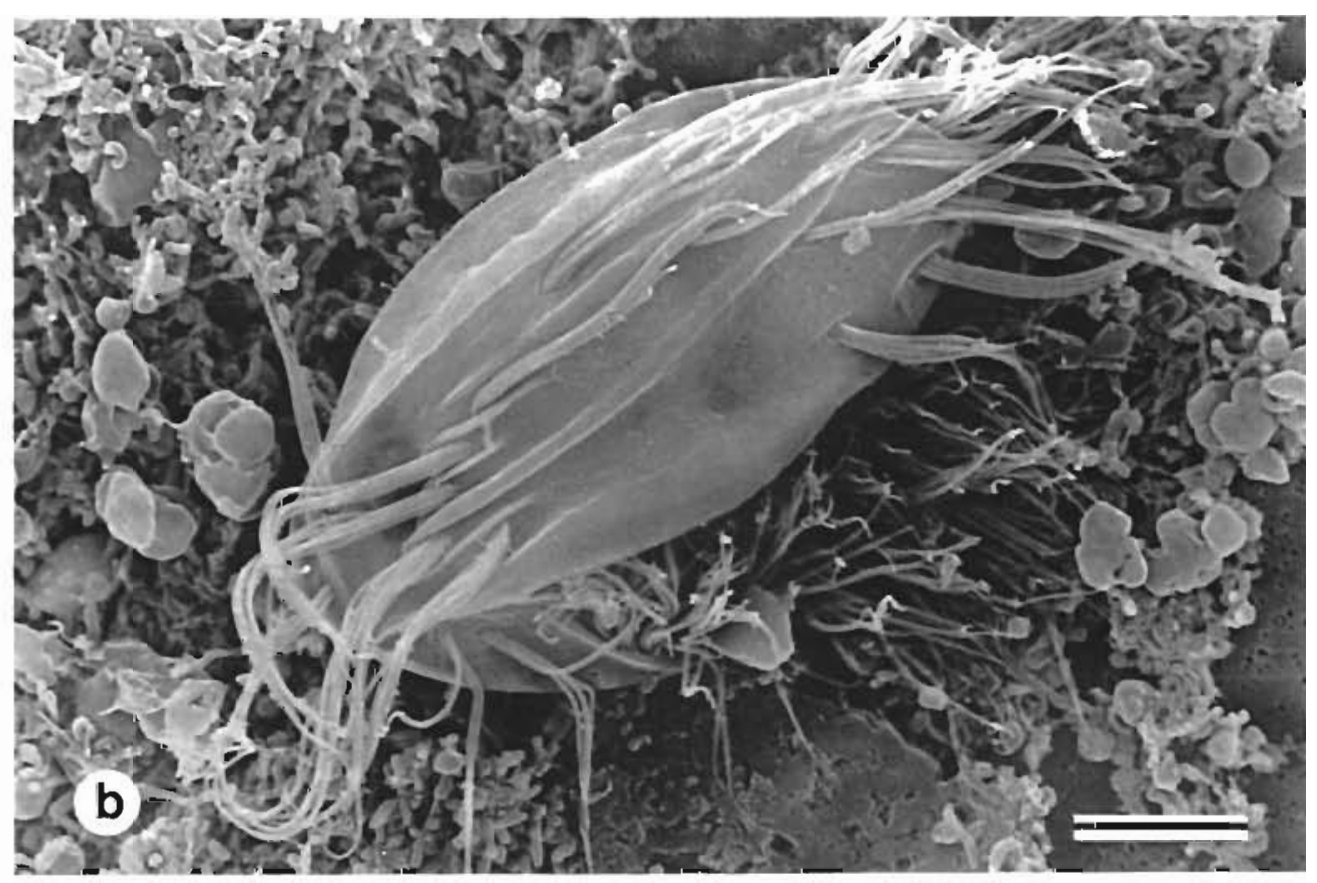




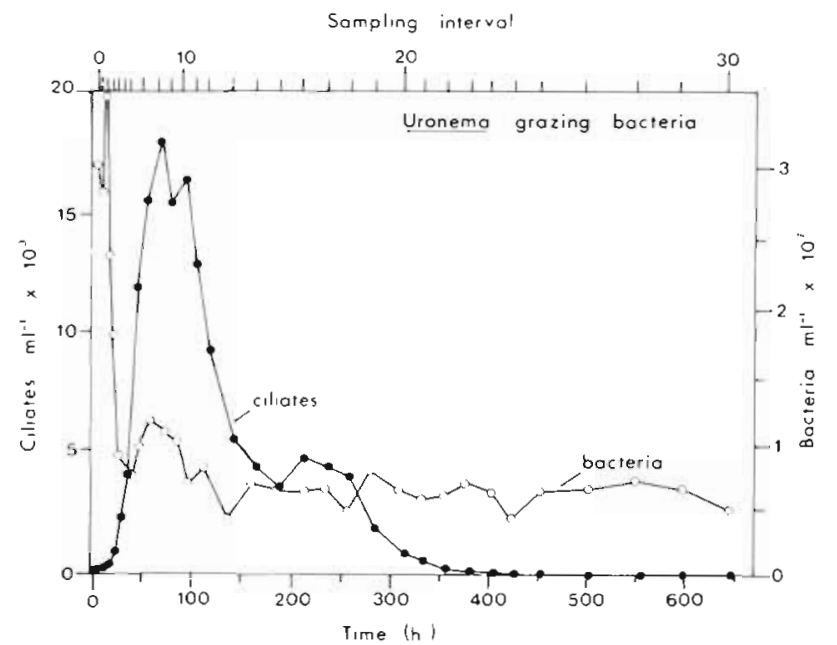

Fig. 3. Uronema sp. Populations of the ciliate and of its bacterial prey as a function of incubation time in shaken batch cultures

function of incubation time (see also Hamilton \& Preslan 1969, Parker 1976). Fig. 6 shows that the cell volume of Uronema declined from approximately $4000 \mu^{3}$ at the start of the experiment to approximately $800 \mu \mathrm{m}^{3}$ when the population density was at its maximum of $10 \times 10^{3}$ cells $\mathrm{ml}^{-1}$ at $60 \mathrm{~h}$. Conversely, the cell volume of Euplotes increases to a maximum of ca $9000 \mu \mathrm{m}^{3}$ at $50 \mathrm{~h}$, somewhat before the peak in cell density of $2.7 \times 10^{3}$ cells $\mathrm{ml}^{-1}$ at $87 \mathrm{~h}$. An increase in cell numbers is thus associated with a decrease in cell size in Uronema whereas the reverse is true of Euplotes. The subsequent decline in Euplotes cell volume may reflect the inability of bacterial production to sustain the growth requirement of the ciliate during the later phase of the incubation period. These

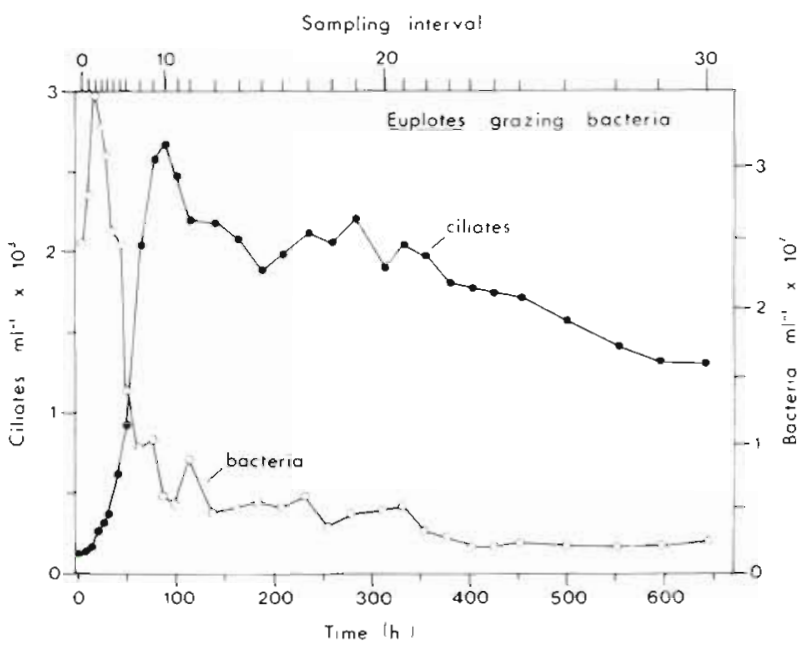

Fig. 4. Euplotes sp. Populations of the ciliate and of its bacterial prey as a function of incubation time in shaken batch cultures

changes in Uronema and Euplotes cell volume can also be seen in the multidimensional (Fig. $9 \& 10$ ) and contour (Fig. 11) plots of ciliate carbon in the different Coulter Counter channels.

Data on growth and mortality of the 2 ciliates are summarised in Fig. 5 and Table 2. Clearly, the rapidly motile Uronema sp. has a higher growth rate $\left(\mu_{n}{ }^{\prime}\right)$ of $3.32 \mathrm{~d}^{-1}$ and responds rapidly to the presence of bacterial food with a doubling time $\left(D_{n}{ }^{\prime}\right)$ of only $5.01 \mathrm{~h}$. At the same time, its mortality rate $\left(\mathrm{M}_{\mathrm{n}}{ }^{\prime}\right)$ is relatively high $\left(0.32 \mathrm{~d}^{-1}\right)$ compared with Euplotes and its mortality time $\left(\mu \mathrm{M}^{\prime}\right)$ therefore short at $50.9 \mathrm{~h}$ once the bacterial food resource has become limiting. Under these conditions Uronema sp. therefore appears to be primarily an opportunistic ciliate adapted to exploit transitory
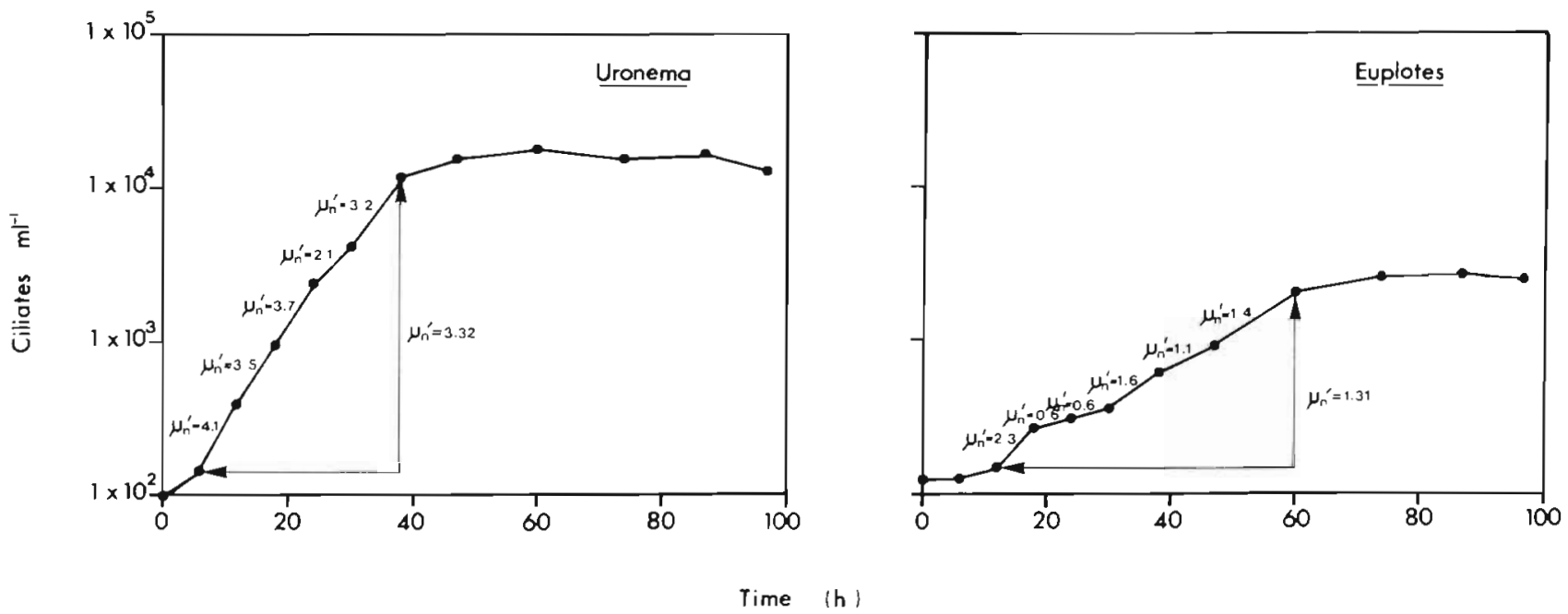

Fig. 5. Logarithmic changes in Uronema sp. and Euplotes sp. numbers as a function of time. Mean relative growth rates $\left(\mu n^{\prime}, \mathrm{d}^{-1}\right)$ between each sampling period are given, as is the mean relative growth rate over the exponential part of each of the growth curves 
Table 2. Growth and mortality measurements of the ciliates Uronema sp. and Euplotes sp. Estimates from growth curves (Fig. 3 to 5) with bacteria as food

\begin{tabular}{|lcc|}
\hline & Uronema sp. & Euplotes sp. \\
\hline Growth rate $\left(\mu_{n}, \mathrm{~d}^{-1}\right)$ & 3.32 & 1.31 \\
Doubling time $\left(\mathrm{D}_{\mathrm{n}}^{\prime}, \mathrm{h}\right)$ & 5.01 & 12.70 \\
Mortality rate $\left(\mathrm{M}_{\mathrm{n}}^{\prime}, \mathrm{d}^{-1}\right)$ & 0.327 & 0.023 \\
Mortality time $\left(\mu \mathrm{M}^{\prime}, \mathrm{h}\right)$ & 50.9 & 723.0 \\
Gross growth efficiency (\%) & 26.7 & 18.7 \\
\hline
\end{tabular}

patches when bacterial prey abundance exceeds a concentration of ca $6 \times 10^{6}$ cells $\mathrm{ml}^{-1}$ (Fig. 3, Fenchel 1980b).

Corresponding values for Euplotes are also shown in Fig. 5 and Table 2. In contrast to Uronema, the growth rate $\left(\mu_{n}{ }^{\prime}\right)$ of $1.31 \mathrm{~d}^{-1}$ is slower than for Uronema and the doubling time $\left(\mathrm{D}_{\mathrm{n}}{ }^{\prime}\right)$ of ca $12.7 \mathrm{~h}$ implies a slower response to peaks in bacterial food supply. Mortality rate $\left(\mathrm{M}_{n}{ }^{\prime}\right)$ of $0.023 \mathrm{~d}^{-1}$ is, however, considerably lower than in Uronema and mortality time $\left(\mu \mathrm{M}^{\prime}\right)$ is as much as $723 \mathrm{~h}$, presumably associated with the presence of a residual bacterial food supply. This suggests that relative to Uronema, under the conditions of our experiment, the slower moving Euplotes has a more persistent strategy which favours a stable equilibrium with its food supply (see also Taylor 1978, Taylor \& Shuter 1981). Whether these reflect genotypic differences between the 2 species which would be reflected in values for maximum specific growth rate under steady-state conditions is not yet known.

The estimate of gross growth efficiency of Uronema is $26.7 \%$ compared with $18.7 \%$ for Euplotes. This is in general agreement with values of 5 to $20 \%$ for Uronema sp. (Hamilton \& Preslan 1970, Rubin \& Lee 1976), 2 to $12 \%$ for Euplotes (Rubin \& Lee 1976), 3 to $11 \%$ for Colpidium (Laybourn \& Stewart 1975) and $6.5 \%$ for Strombidium (Scott 1985) but is less than the 37 to $54 \%$ reported for Tetrahymena by Curds \& Cockburn (1971). These values imply that 70 to $80 \%$ of the carbon entering the ciliates is dissipated through respiration and excretion, and that the step from bacteria to ciliates is therefore a potentially important site of regeneration in the microbial food web.

\section{Impact of grazing on bacterial prey}

The relative proportions, expressed as a percentage of the total bacterial population, of the 8 different bacterial morphs in the presence of each of the ciliates and in grazer-free incubations are plotted as a function of sampling interval in Fig. 7. In the presence of both Uronema and Euplotes there is a marked change in bacterial population structure from an assemblage dominated by cocci, squat rods and large rods to one where small thin rods and mini cocci predominate from sample time $8\left(\sim 70 h_{i}\right.$ Fig. 6) onwards. Although minicocci comprise up to $30 \%$ of the total bacterial

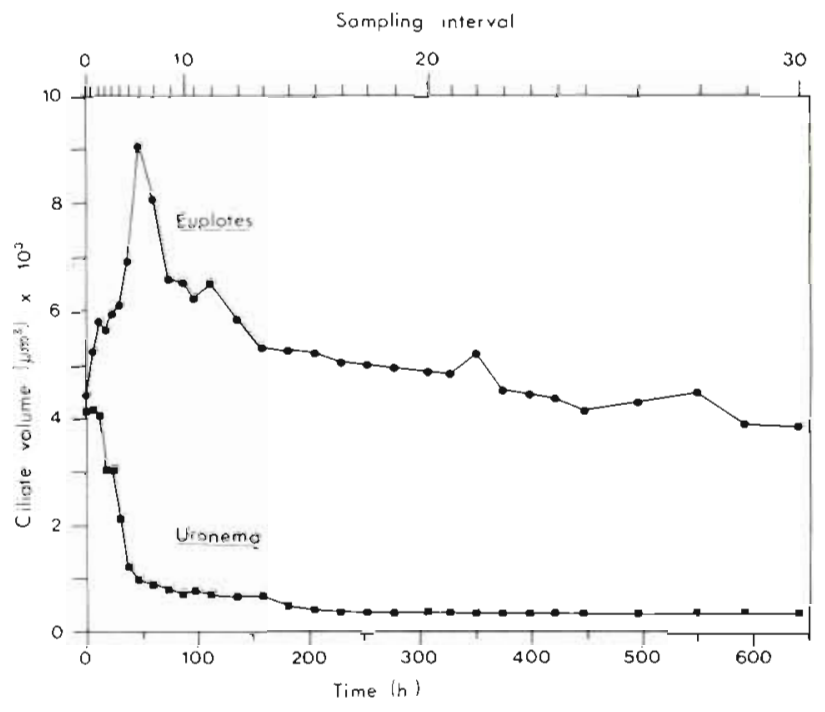

Fig. 6. Changes in mean cell volume $\left(\mu \mathrm{m}^{3} \times 10^{3}\right)$ of Uronema sp. and Euplotes sp. as a function of incubation time

population (Fig. 7), when expressed in terms of their carbon equivalent, they are insignificant (Fig. $9 \& 10$ ). In contrast, in the absence of grazers, cocci, squat rods and large rods remain an important component of the bacterial population throughout the incubation period. Their removal by grazing ciliates is thus followed by the development of a different bacterial assemblage.

Frequency of dividing and divided cells (FDDC) is plotted as a function of incubation time in Fig. 8. This shows that the initial bacterial assemblage of cocci, squat rods and large rods, which can grow from one morphotype to another, has a high value of ca $40 \%$ FDDC. The assemblage which is dominated by small thin rods after $70 \mathrm{~h}$, however, has a much lower FDDC of ca $10 \%$, which in the case of Uronema is sustained even after the disappearance of the predator. The lower rate of FDDC by the secondary bacterial population is therefore not an artifact imposed by selective removal of growing and dividing cells by the predator.

\section{Predator-prey interactions}

The carbon equivalent of bacterial biomass in the presence and absence of grazers, and the net incorporation of carbon into ciliate biomass, is shown for Uronema in Fig. 9 and for Euplotes in Fig. 10. In both cases the initial loss of carbon from the cocci, squat 
Relative proportion of bacterial morphs (Expressed as a percentage of total bacterial population)

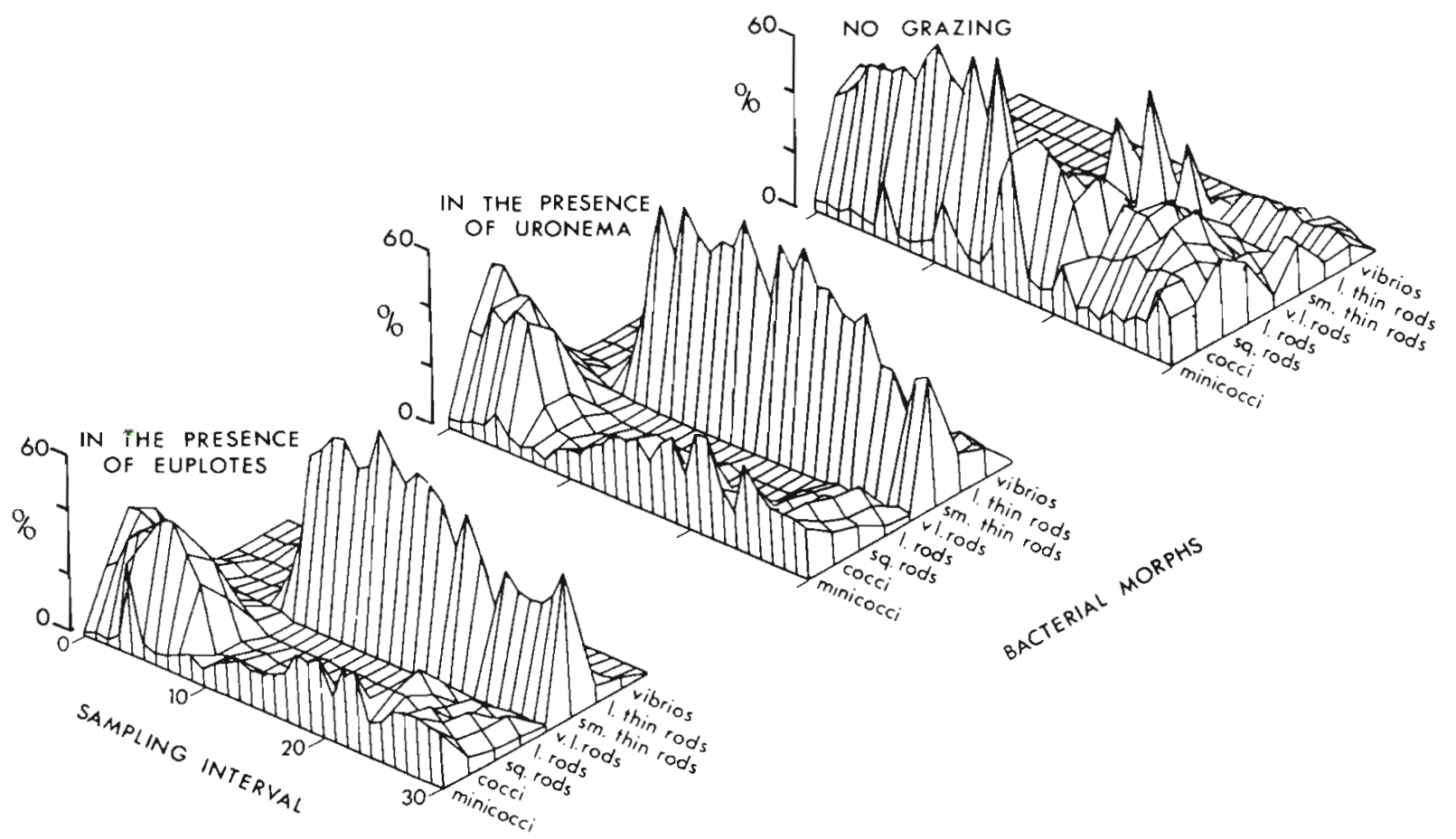

Fig. 7. Multidimensional plots showing relative proportions of bacterial morphs and sizes expressed as a percentage of total bacterial population and as a function of sampling interval in the absence of grazers, in the presence of Uronema and in the presence of Euplotes. Dimensions of bacterial size classes and morphs are shown in Table 1
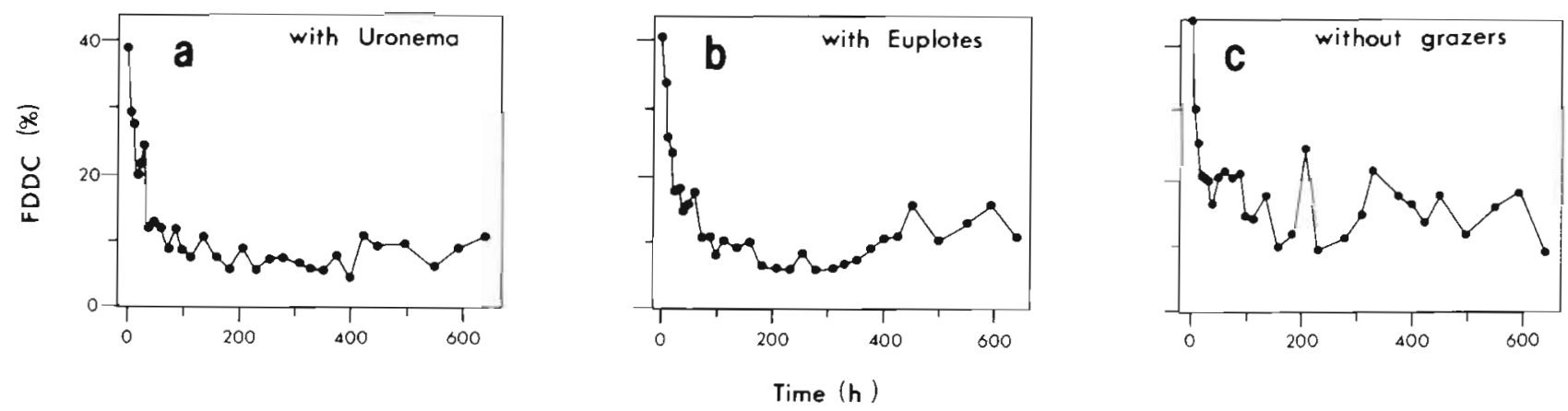

Fig. 8. Frequency of dividing and divided cells (FDDC) of bacteria as a function of incubation time. (a) With Uronema sp. and (b) with Euplotes sp. as bacterial grazers; (c) without grazers

rods and large rods is followed by an increase in the ciliate carbon and by a simultaneous increase of carbon in the small thin rods. The relatively sharp decline in Uronema biomass from sampling interval 11 ( 100 h) onwards is in marked contrast to the slower decline of the Euplotes biomass which had decreased to ca $30 \%$ of the peak biomass by the end of the experiment. The control vessels show that when no grazers are present, the bacterial population of cocci, squat rods and large rods survive for longer than when grazers are present and there is no appearance of the bacterial population dominated by long thin rods which occurs in the presence of grazing ciliates (see also Fig. 11e).

The quantitative relations between ciliates and bacterial prey are summarised in the contour diagrams shown in Fig. 11. In both cases there is some evidence of an initial removal of large rods and squat rods, followed by removal of the smaller cocci before the initial population of bacteria is consumed, i.e. both Uronema and Euplotes appear to exploit the larger components of the bacterial assemblage before utilising the smaller cocci (see also Fenchel 1980a). 
Fig. 9. Multidimensional plots showing carbon equivalent of bacterial biomass incorporated in the 8 bac terial morphs and sizes (see Table 1 for their dimensions) in the presence and absence of Uronema sp. as a function of sampling interval. Net incorporation of carbon into the biomass of Uronema sp. in the different Coulter Counter channels and their equivalent spherical diameter (ESD) also shown
Fig. 10. Multidimensional plots showing carbon equivalent of bacterial biomass incorporated in the 8 bacterial morphs and sizes (see Table 1 for their dimensions), in the presence and absence of Euplotes sp. as a function of sampling interval. Net incorporation of carbon into the biomass of Euplotes sp. in the different Coulter Counter channels and their equivalent spherical diameter (ESD) also shown
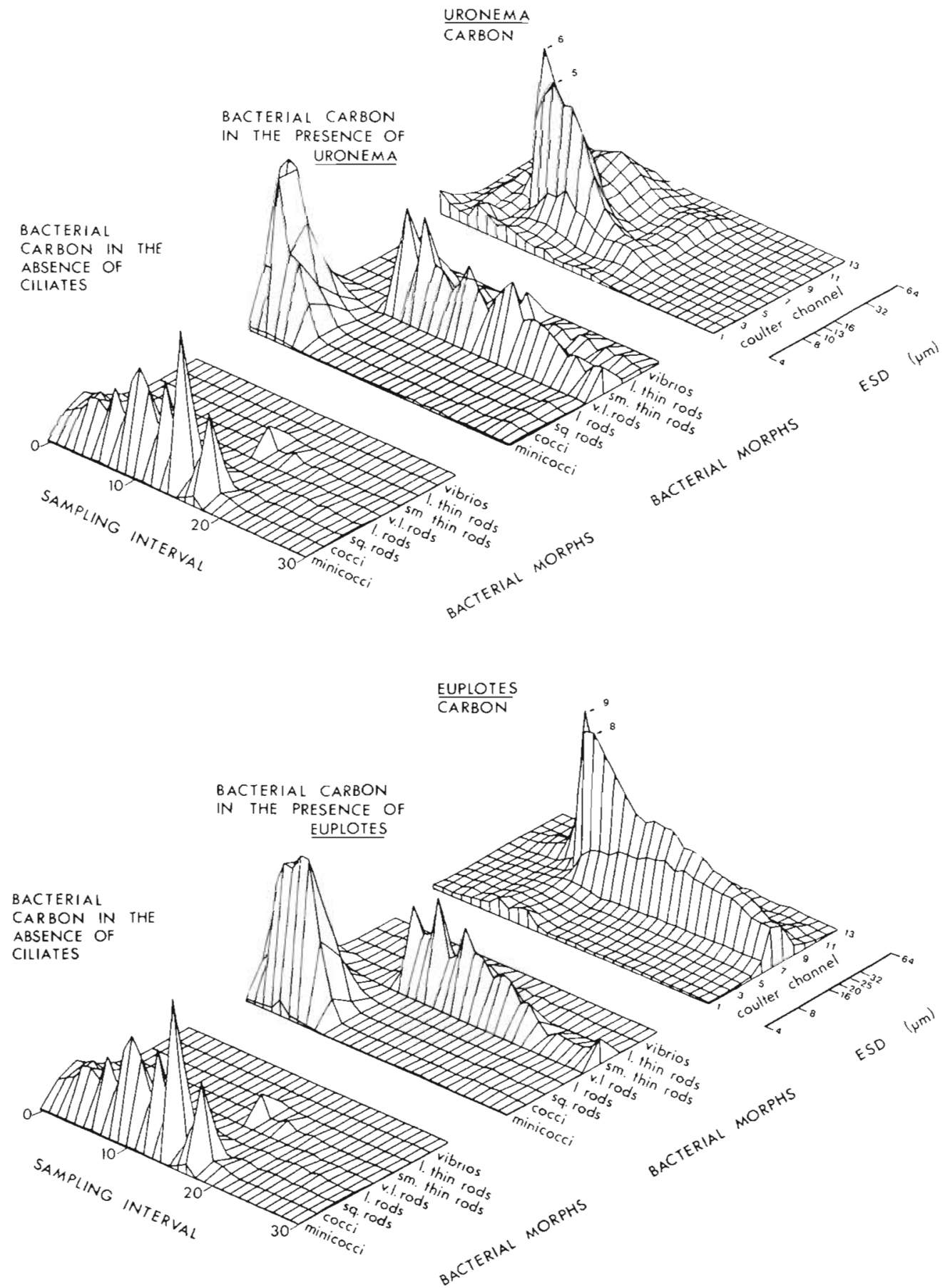

The quantitative relation between the secondary population of bacteria dominated by thin rods and the grazing ciliates can also be seen in Fig. 11. The relatively high carbon equivalent of ciliate biomass reflects the utilisation of bacterial production as well as standing stock, whilst the simultaneous appearance of ciliates and the small thin rods suggests that the secondary bacterial assemblage may be sustained primarily by DOC production associated with the relatively low gross growth efficiency of the ciliates (p. 65).
This supports the results of Taylor et al. (1985) who found that bacteriovory by microzooplankton resulted in grazer-enhanced DOM production.

Carbon biomass of bacteria, 10 to $20 \mu \mathrm{g} \mathrm{l}^{-1}$, in the presence of ciliate grazers is very similar to that recorded under natural conditions in many marine systems (Turley \& Lochte 1985). The grazing activities of Uronema and Euplotes thus appear to regulate size structure and population density of their prey. They may also contribute to bacterial production by supple- 

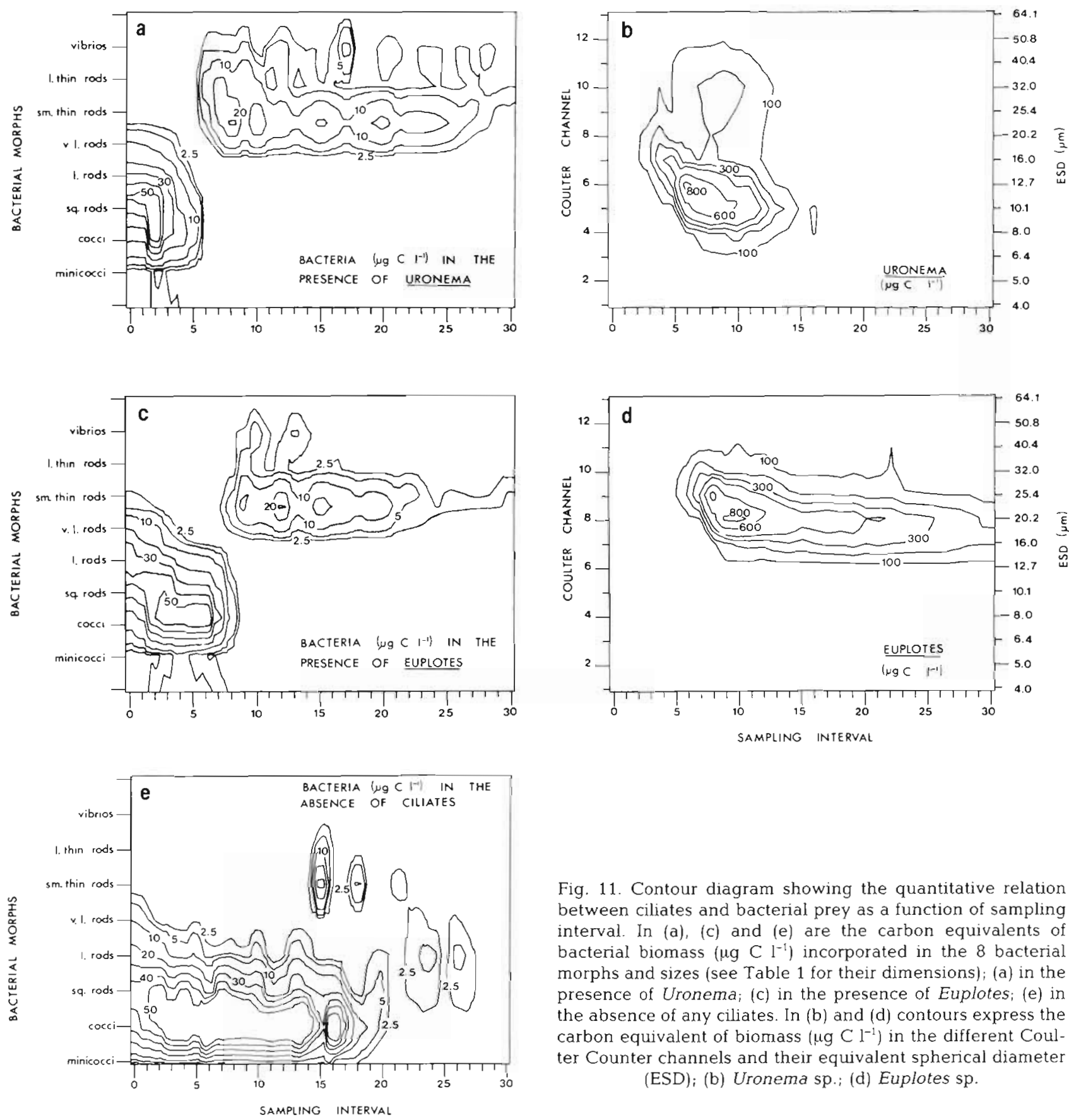

Fig. 11. Contour diagram showing the quantitative relation between ciliates and bacterial prey as a function of sampling interval. In (a), (c) and (e) are the carbon equivalents of bacterial biomass ( $\mu \mathrm{g} \mathrm{C}^{-1}$ ) incorporated in the 8 bacterial morphs and sizes (see Table 1 for their dimensions); (a) in the presence of Uronema; (c) in the presence of Euplotes; (e) in the absence of any ciliates. In (b) and (d) contours express the

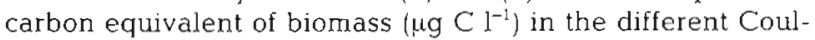
ter Counter channels and their equivalent spherical diameter $(E S D)_{i}$ (b) Uronema sp.; (d) Euplotes sp.

menting the release of extracellular DOM from phytoplankton (see also Davis \& Sieburth 1984).

\section{CONCLUSIONS}

Batch incubations of small marine ciliates, Uronema sp. and Euplotes sp., in the presence of bacterial prey indicate different growth strategies of 2 ciliates.
Uronema sp. moves rapidly and has a relatively high growth rate compared to Euplotes sp. and it responds rapidly to the presence of bacterial food with a doubling time of only $5 \mathrm{~h}$ under the conditions of our experiment. Its population declines rapidly when bacterial food resources become limiting below ca $6 \times 10^{6}$ cells $\mathrm{ml}^{-1}$.

Ciliate volume is also related to population density in an apparently adaptive fashion. In Uronema sp., 
exploitation of a high bacterial food density is associated with a rapid increase in cell numbers which reach a peak density of ca $18 \times 10^{3}$ cells $\mathrm{ml}^{-1}$, and with a corresponding decrease in cell volume - a feature which characterizes opportunistic species (Taylor \& Shuter 1981). Uronema sp. may thus exploit transitory patches when bacterial prey abundance exceeds a threshold concentration of ca $6 \times 10^{6}$ cells $\mathrm{ml}^{-1}$ in the marine environment (see also Fenchel 1980a, Sieburth 1984). When food levels decline, it may rely on its rapid motility and fecundity to locate and exploit another zone of high bacterial numbers.

In contrast, the growth rate of Euplotes sp. is slower, attaining a lower population maximum of $2.6 \times 10^{3}$ cells $\mathrm{ml}^{-1}$ in our experiment. The longer doubling time of ca $13 \mathrm{~h}$ also results in a slower response to peaks in bacterial food supply. When food becomes limiting at 2 to $3 \times 10^{6}$ cells $\mathrm{ml}^{-1}$, the Euplotes population declines at a slower rate than that of Uronema. Again, in contrast to Uronema, cell volume increases during exponential growth until food resources become limiting. Cell volume then decreases and the population is sustained at relatively high numbers, presumably by utilisation of stored reserves and cropping of the residual bacterial community. Euplotes thus has a more persistent strategy which favours a stable equilibrium with its food supply and prevents the rapid population decline which characterizes Uronema.

Grazing activities of the 2 ciliates also have an important influence on the abundance and size class structure of their bacterial prey. In both Uronema and Euplotes there is evidence for an initial selection of large rods and squat rods, followed by grazing of cocci before complete removal of the original bacterial population. A secondary bacterial population dominated by small rods develops simultaneously with the occurrence of grazing ciliates and acquires densities similar to those recorded under natural conditions.

Since the secondary bacterial population occurs only in the presence of Uronema and Euplotes, and since there was no DOM release from primary production it seems likely that these bacteria are sustained by extracellular DOM production by the ciliates. Because the gross growth efficiency of Uronema and Euplotes is ca 27 and $19 \%$ respectively, as much as 73 to $81 \%$ of the carbon ingested with the bacterial food may be released as respiratory and organic losses. This may be of major significance in the maintenance of the secondary bacterial population which develops in association with the ciliate predators. The influence of ciliate grazing on bacterial size class structure and the maintenance of a secondary bacterial population in the presence of Uronema and Euplotes emphasizes the close interdependence of ciliate predators and bacterial prey in microheterotrophic food webs.
Acknowledgements. We are grateful to Ms S. M. Chenery of N.E.R.C. Computing Service, Plymouth for her assistance with the multidimensional plots, to Ms S. Harris and Ms N. Allen for assistance with the scanning electron micrographs and to the Marine Blological Association of the U.K., Plymouth for use of the electron microscope facilities. R. C. Newell and C. M. Turley are in receipt of funds from The Royal Society.

\section{LITERATURE CITED}

Andersen, P., Fenchel, T. (1985). Bacterivory by microheterotrophic flagellates in seawater samples. Limnol. Oceanogr. 30: 198-202

Azam, F., Fenchel, T., Field, J. G., Meyer-Reil, L. A., Thingstad, F. (1983). The ecological role of water-column microbes in the sea. Mar. Ecol. Prog. Ser 10:257-263

Barsdate, R. J., Prentki, R. T., Fenchel, T. (1974). Phosphorus cycle of model ecosystem: significance for decomposer food chains and effect of bacterial grazers. Oikos 25: 239-251

Berk, S. G., Colwell, R. R., Small, E. B. (1976). A study of feeding responses to bacterial prey by estuarine ciliates. Trans. Am. microsc. Soc. 95: 514-520

Caron, D. A., Goldman, J. C., Andersen, O. K., Dennett, M. R. (1985). Nutrient cycling in a microflagellate food chain: II. Population dynamics and carbon cycling. Mar. Ecol. Prog Ser. 24: 243-254

Curds, C. R., Cockburn, A. (1971). Continuous monoxenic culture of Tetrahymena pyriformis. J. gen. Microbiol. 66: 95-108

Curds, C. R., West, B. J., Dorahy, J. E. (1974). Euplotes rariseta sp. N. (Protozoa: Ciliatea) a new small marine hypotrich. Bull. Br Mus. nat. Hist. (Zool.) 27: 95-102

Davis, P. G., Sieburth, J. McN. (1984). Estuarine and oceanic microflagellate predation of actively growing bacteria: estimation by frequency of dividing-divided bacteria. Mar Ecol. Prog. Ser. 19: 237-246

Doetsch, R. N., Cook, T M. (1973). Introduction to bacteria and their ecobiology. Univ. Park Press, Baltimore

Fenchel, T (1980a). Suspension feeding in ciliated protozoa: Functional response and particle size selection. Microb. Ecol. 6: 1-11

Fenchel, T. (1980b). Suspension feeding in cilated protozoa: Feeding rates and their ecological significance. Microb Ecol. 6: 13-25

Fenchel, T. (1982a). Ecology of heterotrophic microflagellates. II. Bioenergetics and grwoth. Mar. Ecol. Prog. Ser. 8: 225-231

Fenchel, T. (1982b). Ecology of heterotrophic microflagellates. IV. Quantitative occurrence and importance as bacterial consumers. Mar. Ecol. Prog. Ser. 9: 35-42

Fenchel, T., Small, E. B. (1980). Structure and function of the oral cavity and its organelles in the hymenostome ciliate Glaucoma. Trans. Am. microsc. Soc. 99: 52-60

Fry, J. C., Davies, A. R. (1985). An assessment of methods for measuring volumes of planktonic bacteria, with particular reference to television image analysis. J. appl. Bact. 58: $105-112$

Fuhrman, J. A., Azam, F. (1982). Thymidine incorporation as a measure of heterotrophic bacterioplankton production in marine surface waters: evaluation and field results. Mar. Biol. 66: 109-120

Gast, V. (1985). Bacteria as a food source for microzooplankton in the Schlei Fjord and Baltic Sea with special reference to ciliates. Mar. Ecol. Prog. Ser. 22: 107-120

Gast, V., Horstmann, U. (1983). N-remineralization of phyto- 
and bacterioplankton by the marine ciliate Euplotes vannus. Mar Ecol. Prog. Ser. 13: 55-60

Goldman, J. C., Caron, D. A. (1985). Experimental studies on an omnivorous microflagellate: implications for grazing and nutrient regeneration in the marine microbial food chain. Deep Sea Res. 32: 899-915

Goldman, J. C., Caron, D. A., Andersen, O. K., Dennett, M. R. (1985). Nutrient cycling in a microflagellate food chain: I. Nutrient dynamics. Mar Ecol. Prog. Ser. 24: 231-242

Haas, L. W., Webb, K. L. (1979). Nutritional mode of several nonpigmented microflagellates from the York River Estuary, Virginia. J. exp. mar. Biol. Ecol. 39: 125-134

Hamilton, R. D., Preslan, J. E. (1969). Cultural characteristics of a pelagic marine hymenostome ciliate, Uronema sp. J. exp. mar. Biol. Ecol. 4: 90-99

Hamilton, R. D., Preslan, J. E. (1970). Observations on heterotrophic activity in the eastern tropical Pacific. Limnol Oceanogr. 15: 395-401

Heinbokel, J. F. (1978). Studies on the functional role of tintinnids in the Southern California Bight. I. Grazing and growth rates in laboratory cultures. Mar. Biol. 47: 177-189

Johannes, R. E. (1965). Influence of marine protozoa on nutrient regeneration. Limnol. Oceanogr. 10: 434-442

Johnson, P. W., Xu, H.-S., Sieburth, J. McN. (1982). The utilization of chroococcoid cyanobacteria by marine protozooplankters but not by calanoid copepods. Annls Inst. océanogr., Monaco 58 (S): 297-308

Lamanna, C., Mallette, M. F., Zimmermann, L. (1973). Basic bacteriology: its biological and chemical background, 4th ed. The Williams and Williams Co., Baltimore

Laybourn, J. E. M., Stewart, J. M. (1975). Studies on consumption and growth in the ciliate Colpidium campylum Stokes. J. Anim. Ecol. 44: 165-174

Luria, S. E. (1960). The bacterial protoplasm: composition and organization. In: Gunsalus, I. C., Stanier, R. Y. (ed.) The bacteria, Vol. 1. Academic Press, New York, p. 1-34

Newell, R. C., Linley, E. A. S. (1984). Significance of microheterotrophs in the decomposition of phytoplankton estimates of carbon and nitrogen flow based on the biomass of plankton communities. Mar. Ecol. Prog. Ser. 16: 105-119

Newell, S. Y., Sherr, B. F., Sherr, E. B., Fallon, R. D. (1983). Bacterial response to presence of eukaryote inhibitors in water from a coastal marine environment. Mar. environ. Res. 10: 147-157

Parker, J. G. (1976). Cultural characteristics of the marine ciliated protozoan, Uronema marinum Dujardin. J. exp. mar Biol. Ecol. 24. 213-226

Pomeroy, L. R. (1974). The ocean's food web, a changing paradigm. Bioscience 24: 499-504

Porter, J. R. (1946). Bacterial chemistry and physiology. Wiley, New York

Porter, K. G., Feig, Y S. (1980). The use of DAPI tor identzfying and counting aquatic microflora. Limnol. Oceanogr 25: 943-948

Porter, K. G., Sherr, E. B., Sherr, B. F., Pace, M., Sanders, R. W (1985). Protozoa in planktonic food webs. J. Protozool. 32: 409-415
Rubin, H. A., Lee, J. J. (1976). Informational energy flow as an aspect of the ecological efficiency of marine ciliates. J. theor. Biol. 62: 69-91

Scott, J. M (1985). The feeding rates and efficiencies of a marine ciliate, Strombidium sp., grown under chemostat steady-state conditions. J. exp. mar. Biol. Ecol. 90: 81-95

Sherr, B. F., Sherr, E. B., Berman, T. (1983). Grazing, growth, and ammonium excretion rate of a heterotrophic microflagellate fed with four species of bacteria. Appl. environ. Microbiol. 45: 1196-1201

Sieburth, J. McN. (1979). Sea microbes. Oxford University Press, New York

Sieburth, J. McN. (1984). Protozoan bactivory in pelagic marine waters. In: Hobbie, J. E., Williams, P. J. LeB. (ed.) Heterotrophic activity in the sea. Plenum Press, New York, p. $405-444$

Sieburth, J. McN., Davis, P. G. (1982). The role of heterotrophic nanoplankton in the grazing and nurturing of planktonic bacteria in the Sargasso and Caribbean Seas. Annls Inst. océanogr., Monaco 58 (S): 285-296

Sieracki, M. E., Johnson, P. W., Sieburth, J. McN. (1985). Detection, enumeration, and sizing of planktonic bacteria by image-analyzed epifluorescence microscopy. Appl. environ. Microbiol. 49: 799-810

Sorokin, Y. I. (1981). Microheterotrophic organisms in marine ecosystems. In: Longhurst, A. R. (ed.) Analysis of marine ecosystems. Academic Press, New York, p. 293-342

Stoecker, D. K. (1984). Particle production by planktonic ciliates. Limnol. Oceanogr 29: 930-940

Strathmann, R. R. (1967). Estimating the organic carbon content of phytoplankton from cell volume or plasma volume. Limnol. Oceanogr. 12: 411-418

Taylor, G. T (1982). The role of pelagic heterotrophic protozoa in nutrient cycling: a review. Annls Inst, océanogr., Monaco 58 (S) : 227-241

Taylor, G. T., Iturriaga, R., Sullivan, C. W. (1985). Interactions of bactivorous grazers and heterotrophic bacteria with dissolved organic matter. Mar. Ecol. Prog. Ser. 23: $129-141$

Taylor, W. D. (1978). Maximum growth rate, size and commoness in a community of bactivorous ciliates. Oecologia (Berl.) 36: 263-272

Taylor, W. D. Berger, J. (1976). Growth responses of cohabiting ciliate protozoa to various prey bacteria. Can. J. Zool. 54: 1111-1114

Taylor, W. D., Shuter, B. J. (1981). Body size, genome size, and intrinsic rate of increase in ciliated protozoa. Am. Nat. 118: $160-172$

Turley, C. M., Lochte, K. (1985). Direct measurement of bacterial productivity in stratified waters close to a front in the Irish Sea. Mar. Ecol. Prog. Ser. 23: 209-219

Turley, C. M., Lochte, K. (1986). Diel changes in the specific growth rate and mean cell volume of natural bacterial communities in two different water masses in the Irish Sea. Microb. Ecol. 12: 121-137

Williams, P. J. LeB (1981). Incorporation of microheterotrophic processes into the classical paradigm of the planktonic food web. Kieler Meeresforsch. (Sonderh.) 5: 1-28 